\title{
31. EARLY AND INTERMEDIATE CHLOROPHYLL DIAGENESIS OF BLACK SEA SEDIMENTS: SITES 379, 380, AND 381
}

\author{
E.W. Baker, ${ }^{1}$ S.E. Palmer,${ }^{1}$ and W.Y. Huang, ${ }^{2}$ Department of Chemistry, \\ Northeast Louisiana University, Monroe, Louisiana
}

\section{INTRODUCTION}

DSDP drilling activities in the Black Sea afforded an opportunity to continue the study of early chlorophyll diagenesis. Since the usual mass spectrometric analysis of thermally labile nonvolatile geochlorins was inadequate for our study, a new analytical mass spectrometric method based on a novel synthesis of a new class of compounds, the silylated hydroxyaluminum chlorins, was developed.

Twenty-five core samples, ranging from 0 to 1062 meters depth of burial (Pleistocene to Miocene) were analyzed. Shallow sediment samples contained chlorins with characteristics similar to those reported for the Pleistocene samples from Leg 15 Site 147 (Baker and Smith, 1973). Chlorins gave way to free-base porphyrins with increasing depth of burial, and small amounts of nickel porphyrins were found in deeper sediments.

The importance of depth of burial as a factor in maturation is re-emphasized by these data. All shallow samples $(0-400 \mathrm{~m})$ contain chlorins; however, intermediate diagenetic products (free-base porphyrins) occur in Site 380 samples at 484-1016 meters depth of burial. These deeper samples, containing the intermediate diagenetic products, can stratigraphically correlated with shallower samples of Site 381 where only chlorins are found.

Small amounts of nickel porphyrin were found in Pleistocene samples at and below 484 meters of burial. The distribution of these porphyrins with respect to other pigments present and the geologic age of the enclosing sediments suggest that they are more characteristic of the Pliocene and Miocene sediments than the overlying Pleistocene sediments. Because the distribution of these particular nickel porphyrins do not fit into the expected sequence typical of early and intermediate chlorophyll diagenesis, it is suspected that they migrated from older deeper sediments.

\section{EXPERIMENTAL}

All core samples were stored frozen until time of analysis; 9:1 mixtures of acetone:methanol were used for ball-mill extraction of pigments. Crude extracts of pigments were chromatographed over Sephadex LH-20

\footnotetext{
'Present address: Florida Atlantic University, Department of Chemistry, Boca Raton, Florida.

${ }^{2}$ Present address: University of New Orleans, Department of Biological Sciences, New Orleans, Louisiana.
}

with THF. Further isolation and purification of chlorins and free-base porphyrins was made by $\mathrm{HCl}$ extraction after diazomethane derivitization. Nickel porphyrins were chromatographed over Grade III Alumina with cyclohexane: benzene (50:50). These methods, given sufficient amounts of pigment $(0.5 \mu \mathrm{g}$ and greater), yielded samples of sufficient purity to permit mass spectrometric analysis.

Each step of the sample work-up was monitored by UV-visible spectrophotometry, using a Beckman ACTA CIII scanning spectrophotometer. Representative spectra are reported in Table 1.

A new technique for mass spectrometry of chlorins, silylation of hydroxyaluminum derivatives, was developed. In each case, the chlorin sample ( 9 to $37 \mu \mathrm{g}$ ) was treated with an excess of $\mathrm{LiAlH}_{4}$ in anyhydrous THF (dried over $\mathrm{LiAlH}_{4}$ ) under reflux for two hours (Baker and Billig, 1970). Conversion to the aluminum chelate was shown by the shift in the red band from that of the free-base $(660-668 \mathrm{~nm})$ to that of a typical metallochlorin with a red band at $635-640 \mathrm{~nm}$. Sample work-up was completed by careful addition of redistilled water, producing the hydroxyaluminum chlorin. Chromatography over Alumina Grade III with THF as eluant was used to remove unreacted starting material and then $5 \% \mathrm{H}_{2} \mathrm{O}$ in THF to elute the chlorin derivative. The silylation of the hydroxy group(s) was carried out by treatment with $0.1 \mathrm{ml}$ BSA bis(trimethysilyl)-acetamide in $0.3 \mathrm{ml}$ reaction vials at $80^{\circ} \mathrm{C}$ for $20-30 \mathrm{~min}$. The solvent was evaporated under dry nitrogen and mass spectrometric analyses were made on a DuPont 491-BR mass spectrometer by the direct probe method. The temperature of the source was held at $260^{\circ} \mathrm{C}$ while the probe temperature was slowly raised from $180^{\circ}$ to $260^{\circ} \mathrm{C}$, the volatization range of the silylated components. Multiple scans with increasing temperature were made to record peaks appearing at different temperatures.

The derivitization method provides a convenient, dependable way of obtaining mass spectra of chlorins since silylated hydroxyaluminum chlorins can be easily volatilized at temperatures in the range of $190^{\circ}-230^{\circ} \mathrm{C}$. This is in marked contrast with previous experience where underivitized chlorins yielded inconsistently to mass spectrometry and at times were destroyed on the probe.

Mass spectra of free-base and nickel porphyrins were also recorded using the solid probe. Probe temperatures ranged from $195^{\circ}$ to $220^{\circ} \mathrm{C}$ for free-base porphyrins and $230^{\circ}$ to $240^{\circ} \mathrm{C}$ for nickel porphyrins. Source temperatures were kept at $270^{\circ}$ to $275^{\circ} \mathrm{C}$ while the 
probe temperature was slowly increased, expelling the more volatile nonporphyrin compounds, until the desired probe temperature was reached.

The data obtained from the mass spectrometric analyses of silylated hydroxyaluminum chlorins and the free-base and nickel porphyrins were given in Tables 2 and 3, respectively.

\section{RESULTS}

Three classes of tetrapyrrole pigments were found in the Black Sea: chlorins, free-base, and nickel porphyrins. The individual pigment yields and UVvisible spectrometric data are given in Table 1 . The concentration (log scale) of each class is plotted versus depth of burial and strata from site to site in Figure 1. A brief summary of the results is now presented for each site.

\section{Site 379}

Six samples, ranging from 48 to 458 meters depth of burial, were examined for pigment content. Chlorins were abundant in the upper sections (Table 1, Figure 1), particularly in Section 379B-5-3. Chlorin concentration decreased with increasing depth and pigment was not detectable in Section 379A-50-4. A similar distribution pattern was observed for chlorins isolated from Site 147 (Leg 15) samples where a plot of log of pigment concentration versus depth was approximately linear (Baker and Smith, 1973); however, the range in depth of burial in that case was only 5 to 107 meters. The chlorin concentration decreases independent of percent organic carbon in both the Site 379 and Site 147 samples. Mass spectrometric analyses of chlorins obtained from this site are discussed together with those from Site 380. Data are given in Table 2.

No free-base or metalloporphyrins (or metallochlorins) were found in these samples, indicating that chlorophyll diagenesis had not progressed into the intermediate (free-base) stages.

\section{Site 380}

Fifteen Pleistocene, Pliocene, and Miocene samples, ranging from 0 to 1062 meters depth of burial, contained pigments ranging with depth from free-base

TABLE 1

Sample and Pigment Data Obtained From Black Sea Cores, Sites 379, 380, and 381

\begin{tabular}{|c|c|c|c|c|c|c|c|c|c|c|c|c|c|c|c|}
\hline \multirow{2}{*}{$\begin{array}{r}\text { Section } \\
379 \mathrm{~B}-4-2\end{array}$} & \multirow{2}{*}{$\begin{array}{c}\text { Geologic Age }{ }^{a} \\
\text { Pleistocene }\end{array}$} & \multirow{2}{*}{\begin{tabular}{l}
\multicolumn{1}{c}{$\begin{array}{c}\text { Lithologic } \\
\text { Description }\end{array}$} \\
$\begin{array}{l}\text { Calc. dark gray } \\
\text { mud }\end{array}$
\end{tabular}} & \multirow{2}{*}{$\begin{array}{c}\begin{array}{c}\text { Depth of } \\
\text { Burial }^{\mathrm{a}} \\
\text { (m) }\end{array} \\
47.548 .5\end{array}$} & \multirow{2}{*}{$\begin{array}{c}\begin{array}{c}\text { Organic } \\
\text { Carbon } \\
\text { (\% by wt) }\end{array} \\
\text { approx. } \\
0.20\end{array}$} & \multirow{2}{*}{$\begin{array}{c}\begin{array}{c}\text { Individual } \\
\text { Yield }^{\mathrm{b}} \\
\text { (ug/g) }\end{array} \\
0.98\end{array}$} & \multicolumn{9}{|c|}{$\begin{array}{l}\text { UV-Visible Absorption Spectra } \\
\text { (nanometers) }\end{array}$} & \multirow[t]{2}{*}{ Pigment Type } \\
\hline & & & & & & & 409 & & & 535 & & 605 & & 663 & \\
\hline 379B-5-3 & Pleistocene & Calc. dark gray & $77.5-78.5$ & 0.51 & & $\int_{12}^{12}$ & 410 & 507 & & 535 & & 605 & & 663 & Chlorin \\
\hline & & mud & & & 30 & $\left\{\begin{array}{r}10 \\
7\end{array}\right.$ & $\begin{array}{l}412 \\
409\end{array}$ & $\begin{array}{l}505 \\
500\end{array}$ & & $\begin{array}{l}537 \\
530\end{array}$ & & $\begin{array}{l}607 \\
605\end{array}$ & & $\begin{array}{l}666 \\
668\end{array}$ & Chlorin \\
\hline $379 \mathrm{~B}-9-3$ & Pleistocene & $\begin{array}{l}\text { Calc, datk gray } \\
\text { mud }\end{array}$ & $153.5-1555$ & $\begin{array}{l}\text { approx. } \\
0.70\end{array}$ & 1.27 & & 409 & 500 & & 535 & & $\begin{array}{l}605 \\
605\end{array}$ & & $\begin{array}{l}008 \\
664\end{array}$ & $\begin{array}{l}\text { Chlorin } \\
\text { Chlorin }\end{array}$ \\
\hline $379 A-25-6$ & Pleistocene & $\begin{array}{l}\text { Cale. dark gray } \\
\text { shale }\end{array}$ & $233-234$ & 0.66 & 0.14 & & 406 & & & 532 & & 600 & & 660 & Chlorin \\
\hline $379 A-46-1$ & Pleistocene & $\begin{array}{l}\text { Calc. med. gray } \\
\text { shale }\end{array}$ & 415.5416 .5 & 0.18 & 0.002 & & & & & & & & & 665 & Chlorin \\
\hline $379 A-50-4$ & Pleistocene & $\begin{array}{l}\text { Calc. gray- } \\
\text { green shale }\end{array}$ & $458-459$ & 0.28 & none & & & & & & & & & & \\
\hline $380-0-2$ & Pleistocene & Calc, gray mud & $1.5 \cdot 3$ & & 0.50 & & 409 & 500 & & 535 & & 605 & & 666 & Chlorin \\
\hline $380-10-3$ & Pleistocene & $\begin{array}{l}\text { Calc. brown } \\
\text { gray mud }\end{array}$ & $89-90$ & & 0.33 & & 408 & 500 & & 535 & & 605 & & 663 & Chlorin \\
\hline $380-13-2$ & Pleistocene & $\begin{array}{l}\text { Calc. dark gray } \\
\text { mud }\end{array}$ & $115.5-117$ & & 0.14 & & 407 & 500 & & 535 & & 600 & & 658 & Chlorin \\
\hline $380-25-3$ & Pleistocene & $\begin{array}{l}\text { Slightly calc. } \\
\text { dark gray mud }\end{array}$ & $231-232.5$ & & trace & & & & & & & & & $(660)$ & Chlorin \\
\hline $380-39-2$ & Pleistocene & $\begin{array}{l}\text { Calc. dark gray } \\
\text { mud }\end{array}$ & $330-330.5$ & & 0.14 & & (407) & & & & & 605 & & 662 & Chlorin \\
\hline $380 A-3-3$ & Pleistocene & $\begin{array}{l}\text { Calc. layers of } \\
\text { light and med- }\end{array}$ & $354.5 \cdot 356$ & & 0.46 & & 400 & & & & & 595 & & 661 & Chlorin \\
\hline $380 \mathrm{~A}-8-0$ & Pleistocene & $\begin{array}{l}\text { ium gray shale } \\
\text { Calc. dark gray } \\
\text { mud }\end{array}$ & 399 & & 0.005 & 0.25 & $\begin{array}{c}394 \\
(407)\end{array}$ & 495 & & 530 & & 590 & 645 & $\begin{array}{l}666 \\
668\end{array}$ & Chlorin \\
\hline $380 \mathrm{~A}-17-0$ & Pleistocene & Cale, gray mud & 484.5 & & 0.005 & & 394 & & 521 & & 556 & & & & Nickel porphyrin \\
\hline $380 A-21-3$ & Pleistocene & $\begin{array}{l}\text { Calc, dark gray } \\
\text { mud }\end{array}$ & $525.5-527$ & & 0.008 & & 395 & & 521 & & 554 & & & & Nickel porphyrin \\
\hline $380 A-38-4$ & Pliocene & Dark gray mud & $679-680.5$ & & $\begin{array}{l}0.07 \\
0.07 \\
0.02\end{array}$ & & $\begin{array}{l}400 \\
394\end{array}$ & 498 & 521 & 528 & $\begin{array}{l}564 \\
556\end{array}$ & 598 & 618 & 667 & $\begin{array}{l}\text { Chlorin } \\
\text { Free-base porphyrin } \\
\text { Nickel porphyrin }\end{array}$ \\
\hline $380 \mathrm{~A}-47-4$ & Pliocene & Calc. dark gray & $764.5-765.5$ & & 0.07 & & & & & & & & & 665 & Chlorin \\
\hline & & mud & & & $\begin{array}{c}0.17 \\
\text { trace }\end{array}$ & & $\begin{array}{l}400 \\
392\end{array}$ & 498 & 515 & 528 & $\begin{array}{l}564 \\
550\end{array}$ & & 618 & & $\begin{array}{l}\text { Free-base porphyrin } \\
\text { Nickel porphyrin }\end{array}$ \\
\hline $380 \mathrm{~A}-63-1$ & Miocene & Calc. gray mud & $912-913$ & 1.80 & 0.12 & & & & & & & & & 668 & Chlorin \\
\hline & & & & & $\begin{array}{l}2.33 \\
0.05\end{array}$ & & $\begin{array}{l}400 \\
396\end{array}$ & 498 & 518 & 528 & $\begin{array}{l}564 \\
554\end{array}$ & & 618 & & $\begin{array}{l}\text { Free-base porphyrin } \\
\text { Nickel porphyrin }\end{array}$ \\
\hline $380 A-74-1$ & Miocene & $\begin{array}{l}\text { Calc. dark gray } \\
\text { shale }\end{array}$ & $1016.5-1017.5$ & & $\begin{array}{l}1.30 \\
\text { trace }\end{array}$ & & 400 & 498 & & 528 & $\begin{array}{l}564 \\
555\end{array}$ & & 618 & & $\begin{array}{l}\text { Free-base porphyrin } \\
\text { Nickel porphyrin }\end{array}$ \\
\hline $380 A-78-6$ & Miocene & $\begin{array}{l}\text { Calc. gray } \\
\text { shale }\end{array}$ & $1062-1062.5$ & 2.20 & $\begin{array}{l}2.02 \\
0.40\end{array}$ & & $\begin{array}{l}400 \\
395\end{array}$ & 498 & 515 & 528 & $\begin{array}{l}564 \\
551\end{array}$ & & 618 & & $\begin{array}{l}\text { Free-base porphyrin } \\
\text { Nickel porphyrin }\end{array}$ \\
\hline $381-2-3$ & Pleistocene & $\begin{array}{l}\text { Slightly calc. } \\
\text { black shale }\end{array}$ & $12.5-13.5$ & 1.07 & 1.89 & & 409 & & & 534 & & 605 & & 665 & Chlorin \\
\hline $381-9-0$ & Pleistocene & $\begin{array}{l}\text { Calc. gray } \\
\text { shale }\end{array}$ & 76 & 0.42 & 0.006 & & 407 & & & & & & & 659 & Chlorin \\
\hline $381-23-6$ & $\begin{array}{l}\text { Pleistocene/ } \\
\text { Pliocene }\end{array}$ & Gray shale & $207-208.5$ & 0.95 & 0.05 & & & & & & & & & 663 & Chlorin \\
\hline $381-37-3$ & $\begin{array}{l}\text { Pliocenef } \\
\text { Miocene }\end{array}$ & $\begin{array}{l}\text { Calc. gray } \\
\text { shale }\end{array}$ & $335-336.5$ & 5.49 & 3.64 & & 407 & 494 & & & & 597 & & 660 & Chlorin \\
\hline $381-54-5$ & Miocene & $\begin{array}{l}\text { Dark gray } \\
\text { shale }\end{array}$ & $500.5-502$ & 1.72 & $\begin{array}{l}0.04 \\
0.10 \\
0.03\end{array}$ & & $\begin{array}{l}400 \\
395\end{array}$ & 498 & 518 & 528 & $\begin{array}{l}564 \\
552\end{array}$ & & 618 & 644 & $\begin{array}{l}\text { Chlorin } \\
\text { Free-base porphyrin } \\
\text { Nickel porphyrin }\end{array}$ \\
\hline
\end{tabular}

aDates for much of the sedimentary section are still unresolved. Age determinations used here are from Jousé and Mukhina (this volume) and Ross (this volume).

bPigment yield calculated by using the following molar extinction coefficients: pheophytin "a" $=63700$ at $660 \mathrm{~nm}$, free-base porphy rin $=6540$ at $618 \mathrm{~nm}$, and nickel porphyrin $=$ 34820 at $550 \mathrm{~nm}$. 

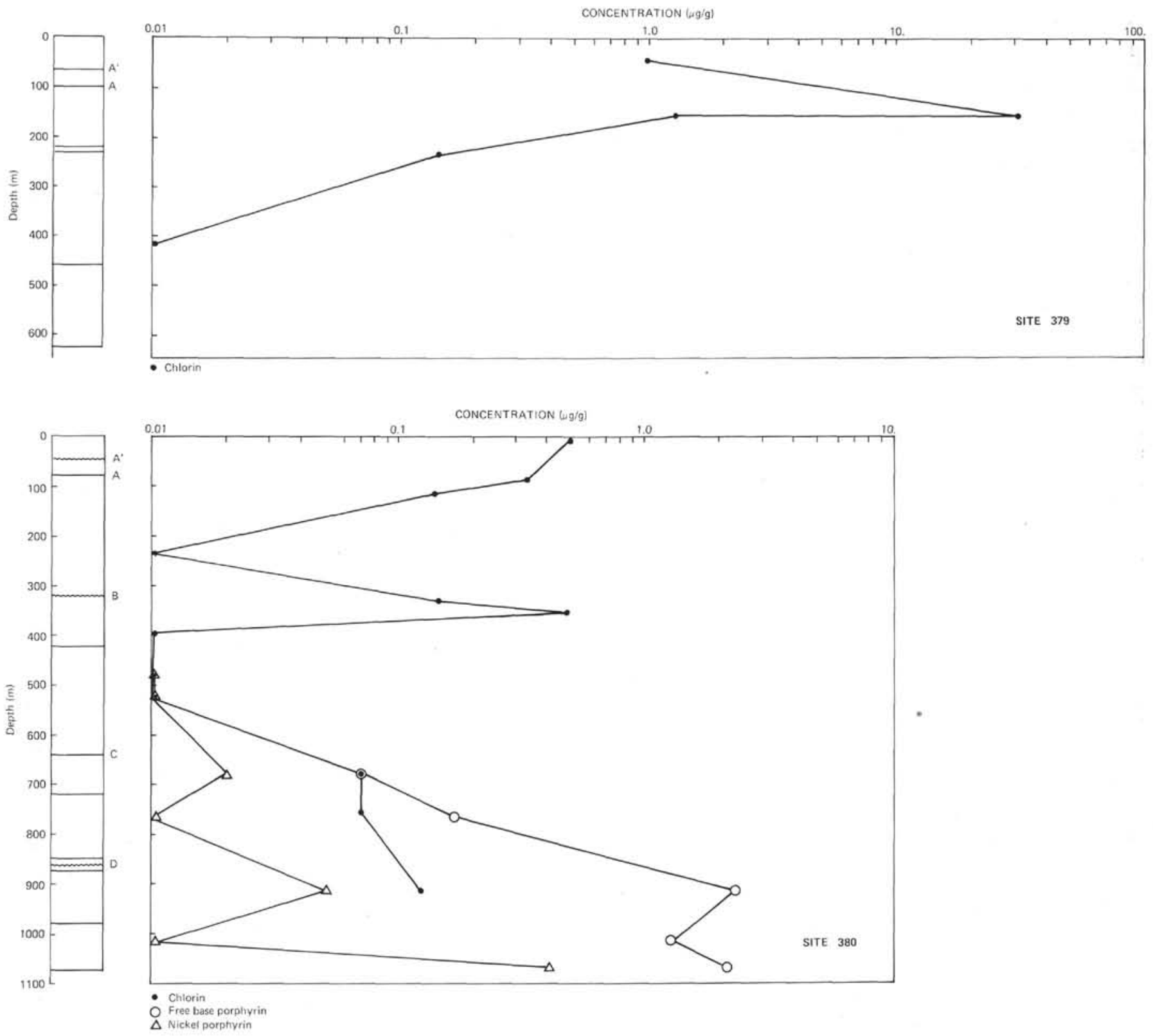

CONCENTRATION ( $\mathrm{mg} / \mathrm{g})$
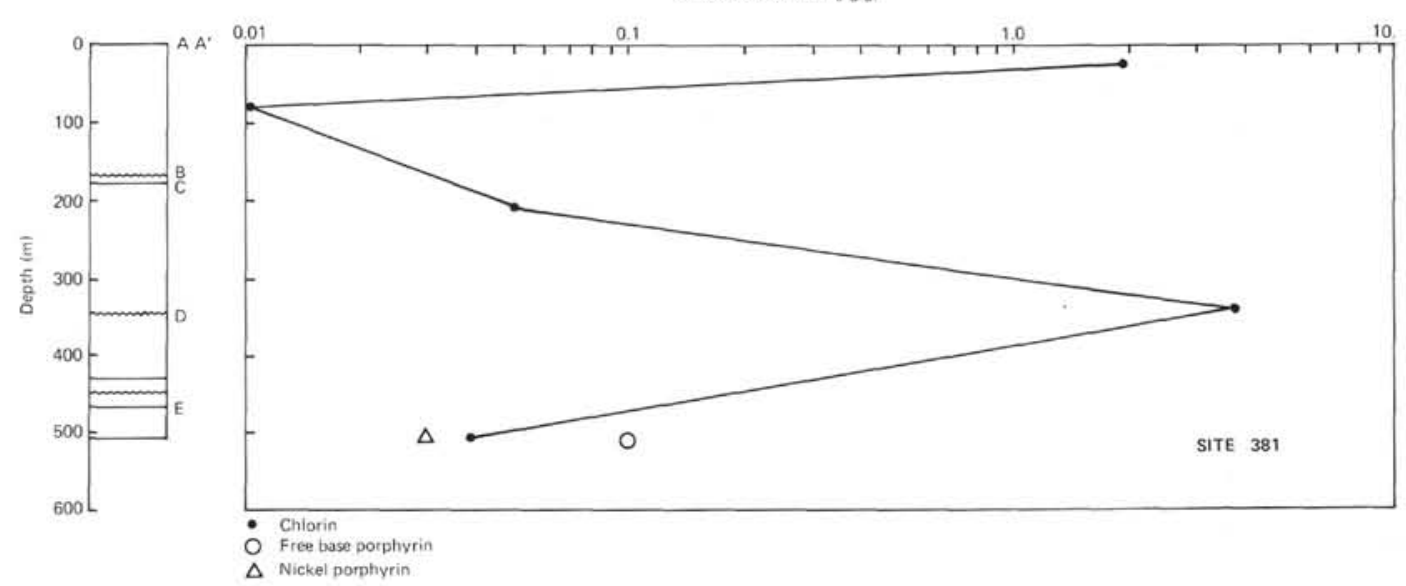

Figure 1. Pigment concentration (log scale) vs. depth of burial, Sites 379, 380, and 381. Data for chlorins $(\bullet)$, free $=$ base porphyrins $(\circ)$, nickel porphyrins $(\Delta)$ plotted here are given in Table 1. Stratigraphy was supplied by DSDP; only those horizons which can be traced from one site to another have been indicated (shown as $A^{\prime}, A, B, C, D$, and E). 
TABLE 2

Mass Spectrometric Data of Silylated Hydroxyaluminum Derivatives of Black Sea Geochlorins and Selected Model Compounds

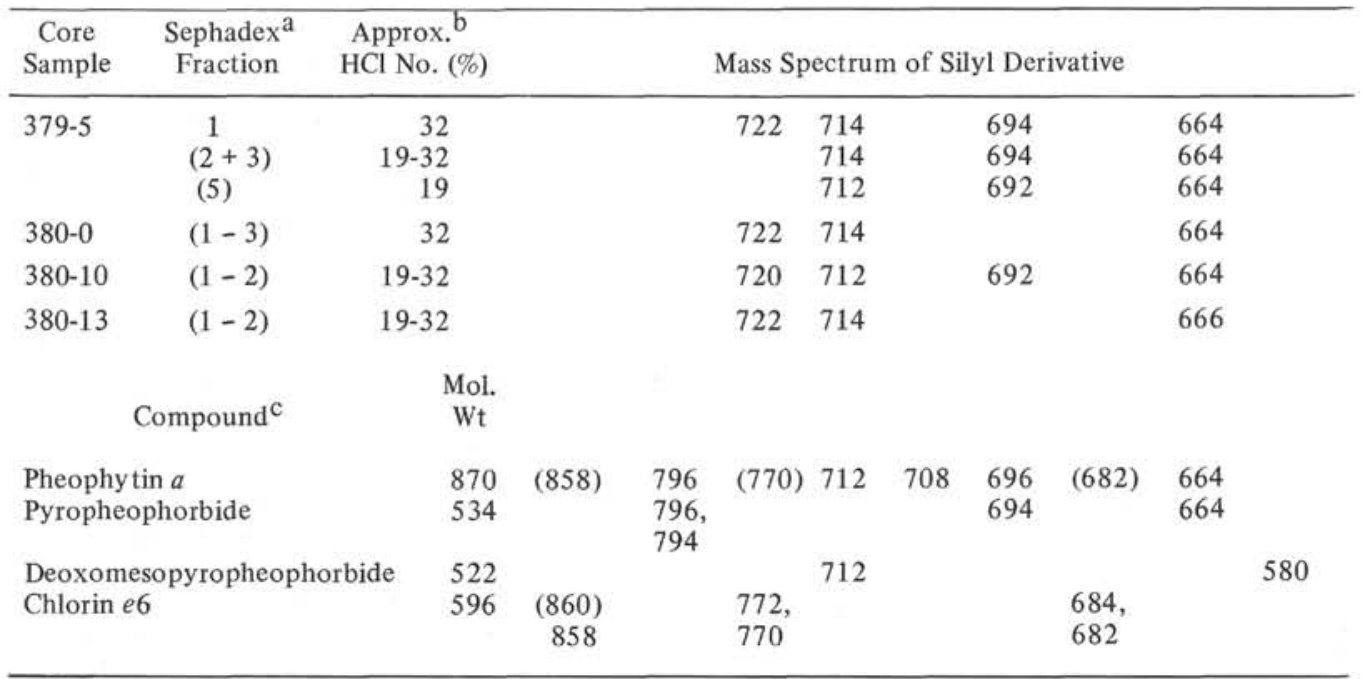

\footnotetext{
${ }^{a}$ Sephadex LH-20 fraction numbers are given to indicate chromatographic behavior of geochlorins; note that only core 379-5 had a substantial amount of late-running chlorin fraction (5).

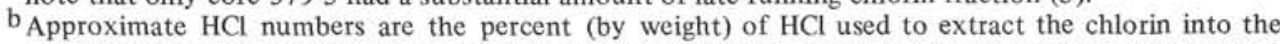
aqueous phase. An $\mathrm{HCl}$ Number of 32 is comparible with that of pheophytin $a(\mathrm{HCl} \mathrm{No} .=28-29)$ while 19 is comparible with pheophorbide $(\mathrm{HCl} \mathrm{No.}=15)$. H. Fischer and A. Stern, Die Chemie des Pyrrols, Band 11: Pyrrolfarbstoffe, Halfte 2, Akad. Verlag., Leiqzig, p. 55 and 59 (1940).

${ }^{\mathrm{c}}$ Structures for these model chlorin compounds are given in Figure 3.
}

chlorins to free-base and nickel porphyrins (Table 1, Figure 1). In contrast with Site 379 , the chlorin concentration did not decrease monotonically with depth, but was greatest near the surface (380-0-2 and $380-10-3)$ and peaked again at 355 meters (380A-3-3).

Nickel porphyrins were found in Cores $380 \mathrm{~A}-17$ and $380 \mathrm{~A}-21$ (484 to $526 \mathrm{~m}$ ) in which chlorins were absent. This finding seemed unusual because chlorins were abundant above and below these two samples; the nickel porphyrins are diagenetically out of place. Mass spectrometric analyses of nickel porphyrins from these cores showed that the molecular weight distributions were markedly different from those previously reported for marine sediments. Earlier, nickel DPEP and etio type porphyrins were reported as the only series (Baker et al., in press a, b). In contrast, these series were nearly absent in the Black Sea nickel porphyrins and a new series $(455+14 n)$ dominated the mass spectra. Molecular weight distributions of the nickel porphyrin fractions from two deeper samples (380A-38 and 380A63) were similar to 380A-17 and 380A-21 (Table 3).

Whereas porphyrins of the etio series were present only at the level of detection in Samples 380A-17, $380 \mathrm{~A}-21,380 \mathrm{~A}-38$, and 380A-63, both nickel DPEP and etio type porphyrins became mass spectrometrically more observable in Core 380A-78.

In all samples, the molecular weights of the new and etio type nickel porphyrins were low, having 29 carbons or less. In previous Initial Reports (Baker et al., in press a, b) nickel porphyrins having 30 to 32 carbons predominated.

Sufficient pigment was available for demetallation of the Core 380A-78 nickel porphyrin fraction. A visible spectrum which could be duplicated by a mixture of rhodo porphyrin and etioporphyrin was obtained (Baker, 1966). Spectra of this nickel porphyrin fraction and its free base are shown in Figure 2.

Free-base chlorins and porphyrins, with the porphyrins predominating, were found in samples below 525 meters (380A-38 to $380 \mathrm{~A}-63$ ); below this depth all pigments increased with depth of burial. These relationships are depicted in Figure 1.

Mass spectrometric analyses of the free-base porphyrins are reported in Table 3. Five to six members of a DPEP homologous series, with $\mathrm{m} / \mathrm{e} 476$ and 462 being the major members, characterize every mass spectrum with the exception of the fraction isolated from Core $380 \mathrm{~A}-47$. In this case, the $\mathrm{m} / \mathrm{e}$ values (530, 516, and 502) may indicate deoxophylloerythrin, a carboxylated porphyrin.

\section{Site 381}

Five samples, from 12 to 500 meters depth of burial, were extracted and their pigment content was compared with those of Sites 379 and 380. Most interesting was the finding that sediments representative of the same geologic age at Site 381 as at Site 380 contained different pigment assemblages (Figure 1). High concentrations of chlorins at 208 to 336 meters (Site 381) are perhaps correlatable with the high concentrations of free-base porphyrins in Site 380 cores at 680 and 765 meters. That sediments of the same age contain pigments of different stages of diagenesis indicates the importance of depth of burial as a maturation rate determining factor.

Free-base porphyrins, whose mass spectra were similar to those of Site 380 samples, were found in Core 381-54 of Miocene age. Nickel porphyrins also present 
TABLE 3

Mass Spectrometric Data of Free-base and Nickel Porphyrins ${ }^{\mathrm{a}}$ From Sites 380 and 381 (peak intensities normalized to 100 for the most intense peak)

\section{A-17 Nickel porphyrin}

506

$492 \quad 484 \quad 478$

464

450

436

Etio series ${ }^{\mathrm{b}}$

\begin{tabular}{rrrrrr}
511 & 497 & 483 & 469 & 455 & 441 \\
\hline 37 & 33 & 87 & 81 & 100 & 442
\end{tabular}

\begin{tabular}{rrrrrr}
513 & 499 & 485 & 471 & 457 & 443 \\
\hline 5 & 5 & 12 & 11 & 15 & 10
\end{tabular}

New series

$455+14 n$

$457+14 n$

380A-21 Nickel porphyrin

478

464

450

436

422

Etio series ${ }^{b}$

\begin{tabular}{rrrrrr}
483 & 469 & 455 & 441 & 427 & 413 \\
\hline 41 & 61 & 77 & 100 & 92 & 79
\end{tabular}

New series

$455+14 n$

\begin{tabular}{rrrrrr}
485 & 471 & 457 & 443 & 429 & 415 \\
\hline 7 & 8 & 13 & 14 & 15 & 12
\end{tabular}

$457+14 n$

380A-38 Nickel porphyrin

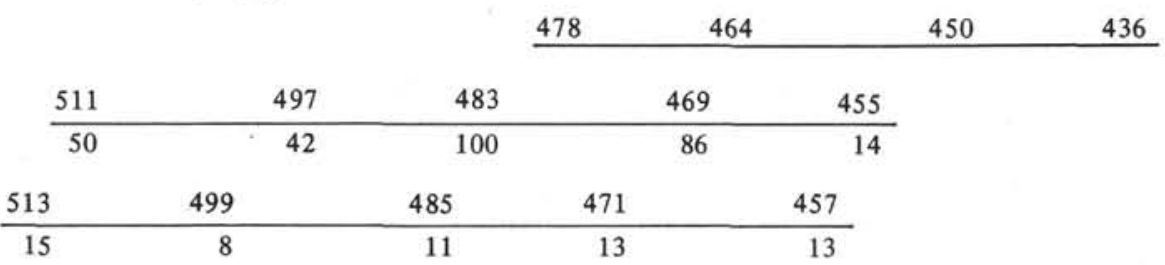

Etio series ${ }^{b}$

New series

$455+14 n$

380-47 Free-base porphyrin

\begin{tabular}{rrr}
530 & 516 & 502 \\
\hline 100 & 55 & 53
\end{tabular}

380A-63 Nickel porphyrin

$532 \quad 518$

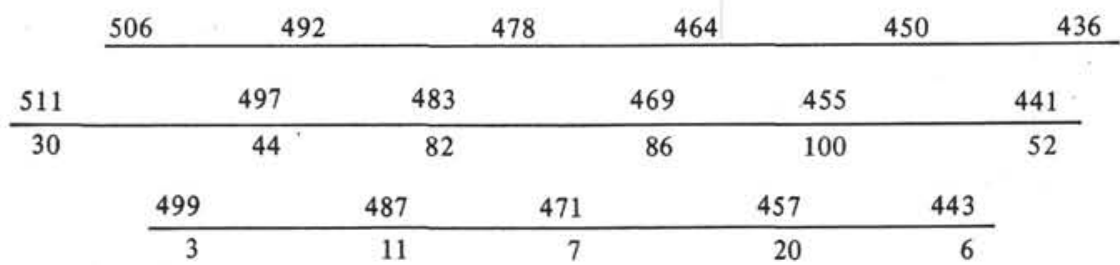

DPEP series ${ }^{b}$

Etio series ${ }^{\mathrm{b}}$

New series

$455+14 n$

$457+14 n$

Free-base porphyrin

\begin{tabular}{rrrrr}
476 & 462 & 448 & 434 & 420 \\
\hline 47 & 100 & 34 & 40 & 19
\end{tabular}

380A-74 Free-base porphyrin

\begin{tabular}{rrrrrr}
476 & 462 & 448 & 434 & 420 & 406 \\
\hline 46 & 100 & 34 & 26 & 9 & 6
\end{tabular}

380A-78 Nickel porphyrin

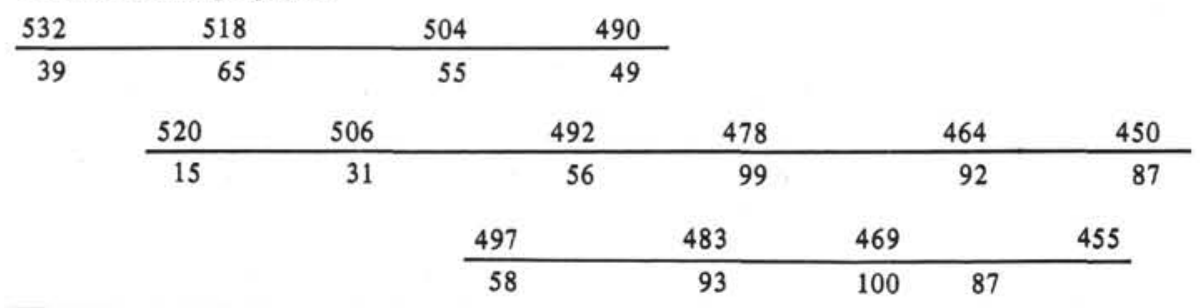

DPEP series

Etio series

New series $455+14 n$ 
TABLE 3 - Continued

380A-78 Nickel porphyrin (Cont)

\begin{tabular}{rrrr}
499 & 485 & 471 & 457 \\
\hline 9 & 13 & 16 & 12
\end{tabular}

$457+14 n$

Free-base porphyrin

\begin{tabular}{rrrrr}
476 & 462 & 448 & 434 & 420 \\
\hline 94 & 100 & 63 & 37 & 22
\end{tabular}

381-54 Nickel porphyrin

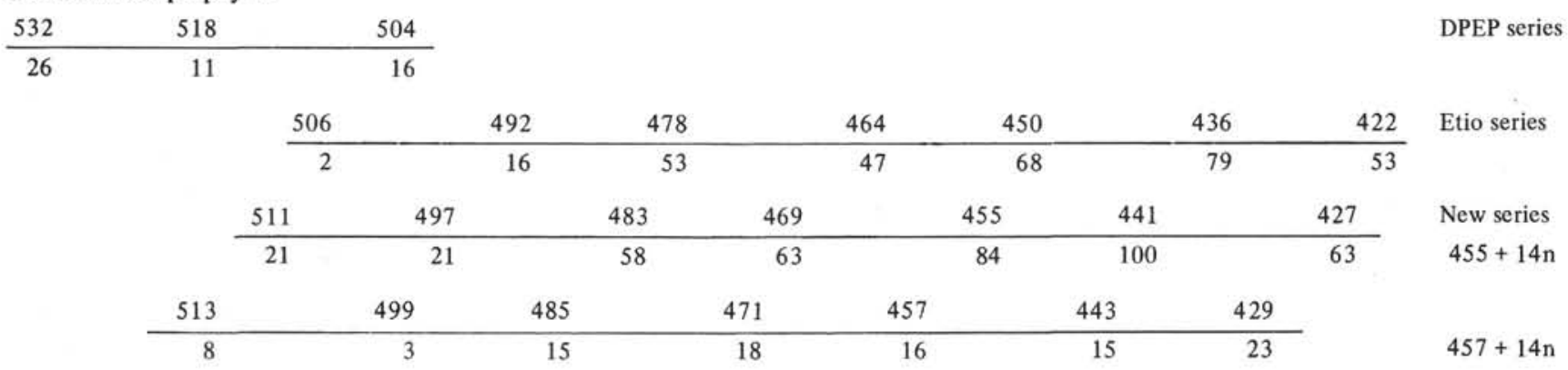

\begin{tabular}{|c|c|c|c|c|c|}
\hline \multicolumn{5}{|c|}{ Free-base porphyrin } & \\
\hline 476 & 462 & 448 & 434 & 406 & \\
\hline 100 & 72 & 69 & 49 & 32 & \\
\hline
\end{tabular}

in this core are similar to those found in Core 380A-78 (Table 3).

\section{Mass Spectrometric Analyses of Silylated Hydroxyaluminum Derivatives of Geochlorins}

Mass spectrometric data of silylated derivatives of Black Sea geochlorins and selected model compounds are given in Table 2. Four synthetic chlorins were selected for use as reference compounds and to serve as indicators of the following diagenetically related structural changes: (1) de-esterification (loss of phytol); (2) reduction of C-9 keto group, (3) decarbomethoxylation at $\mathrm{C}-10$ position; and (4) isocyclic ring opening.

Only a partial structural interpretation of the mass spectra of the model compounds (Figure 3 ) has been made. However, observable differences between them can be pointed out. The $\mathrm{m} / \mathrm{e}$ values of $858,770(772)$, and 682(684) are indicative of chlorin $e_{6}$, a chlorin in which the isocyclic ring is replaced by two carboxyl groups. Due to the basicity of the reaction mixture, rupturing of the isocyclic ring of pheophytin $a$ occurred to some extent; the $\mathrm{m} / \mathrm{e}$ values assigned to chlorin $e_{6}$, therefore, appear along with values characteristic of pheophytin $a(\mathrm{~m} / \mathrm{e}=796,712,708,696$, and 664).

The mass spectrum of the silylated derivative of pyropheophorbide, which lacks phytol and the C-10 carbomethoxyl group, cannot be clearly distinguished from that of pheophytin $a$. Apparently these groups are lost from pheophytin $a$ during the derivatization. The major peaks are: $\mathrm{m} / \mathrm{e}=794(796), 694$ and 664 .

However, when the reduction of the isocyclic ring is complete (loss of carbomethoxyl and keto groups) and the C- 2 vinyl group is reduced to ethyl, as is the case in deoxomesopyropheophorbide, the mass spectrum is simplified and contains two major peaks $(\mathrm{m} / \mathrm{e}=712$ and 580).

Comparison with the mass spectra obtained for the model compounds permits the following statements concerning the structure of the geochlorins to be made: most of the geochlorins can be accounted for as a pheophytin $a$ or pheophorbide type pigment since $\mathrm{m} / \mathrm{e}$ values 712(714), 692(694), and 664(666) are present in the spectra of the unknowns. The significance of the $\mathrm{m} / \mathrm{e}$ values of 720 and 722 is not presently known. That none of the geochlorins can be assigned the structure of deoxomesopyropheophorbide is evidenced by the lack of a major m/e peak at 580 . This observation is reasonable because geochlorins having a structure similar to deoxomesopyropheophorbide would be expected at a much later stage of diagenesis than that of the samples studied. The degree of reduction of this particular model compound places it very close to the chlorin-porphyrin transition. If sufficient amounts of chlorin for derivatization had been present in samples of greater depth of burial, a deoxomesopyropheophorbide type pigment may have been found. (These deeper chlorins were found in association with free-base porphyrins.) 

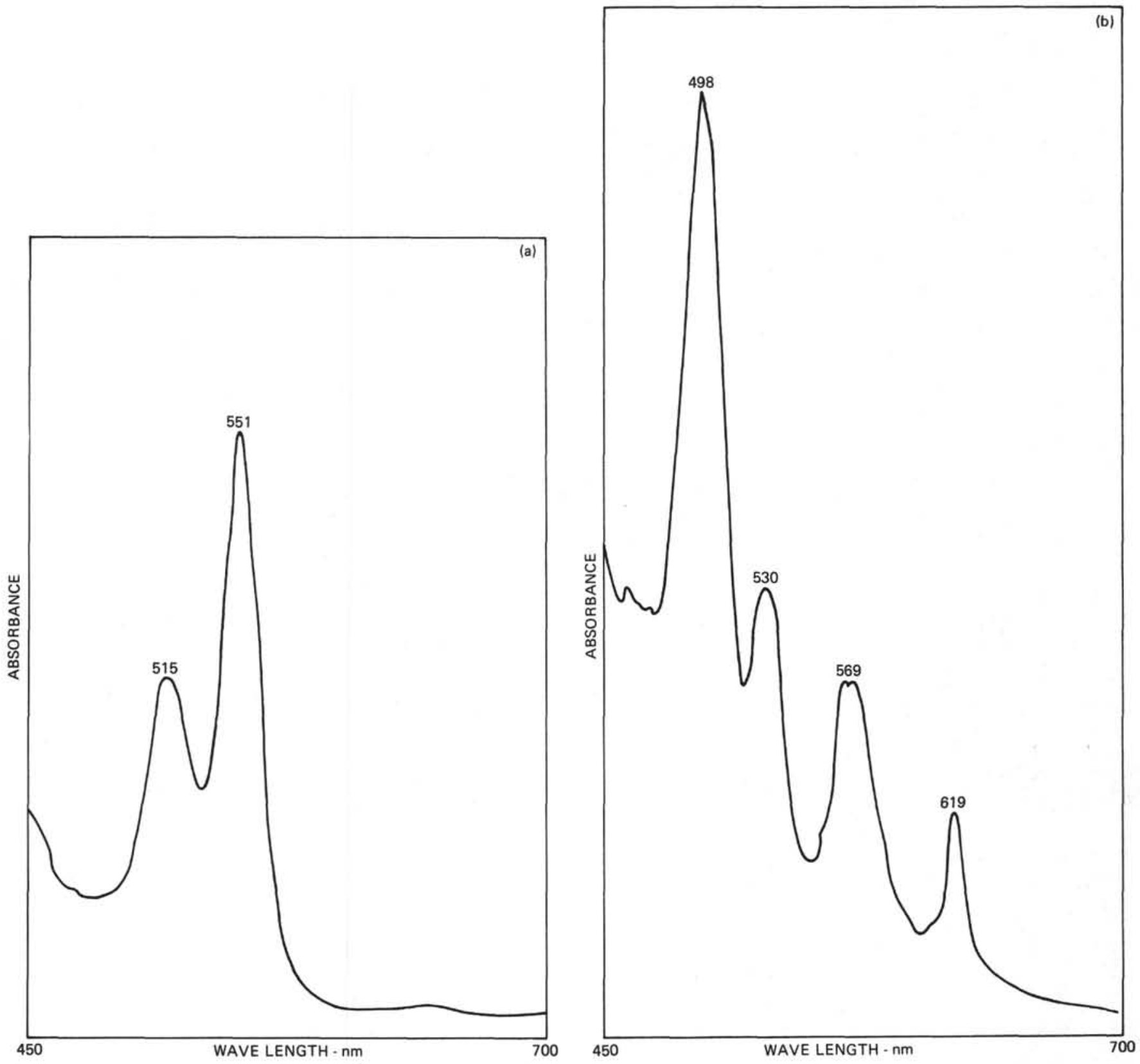

Figure $2(\mathrm{a}, \mathrm{b})$. UV-visible spectra of the nickel porphyrin fraction isolated from Core $381 \mathrm{~A}-78$, before (a) demetallation and after (b).

These data clearly indicate that chlorins with ruptured isocyclic rings, such as chlorin $e_{6}$, are not present in the samples studied. Apparently, conditions during deposition and sediment compaction in the Black Sea were not those that permit isocyclic ring opening. Thus, the route by which chlorins such as chlorin $e_{6}$ are formed was not a major one, if operative at all.

Interpretation of mass spectra of silylated hydroxyaluminum geochlorins can be more complete after additional model chlorins are studied and structures correlated with fragmentation patterns. High resolution mass spectrometry is proposed in order to provide empirical formulas of significant mass spectral fragment ions. As this method is developed, more detailed structural information will become available. However, even at this stage, the method provides new insights into chlorin diagenesis.

\section{Discussion}

Based on the data obtained on 25 samples from the Black Sea, tetrapyrrole diagenesis has progressed from the early stages (pheophytin $\rightarrow$ pheophorbide) to intermediate stages (chlorin-porphyrin transition). Freebase DPEP type porphyrins were abundant in deeper cores of Site 380 , increasing with depth relative to the amount of chlorin present.

The UV-visible and mass spectrometric data of chlorins extracted from core samples of 0 to 200 meters depth of burial are indicative of pheophytin-like 

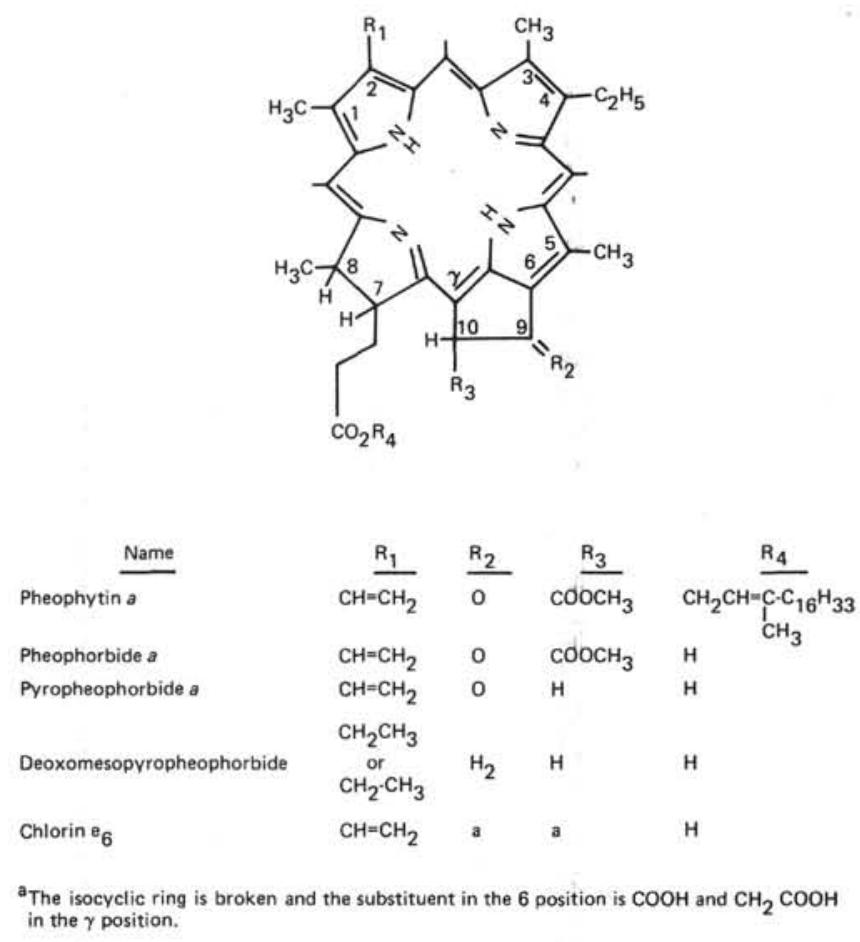

Figure 3. Structures of chlorin model compounds. Note a $=$ the isocylic ring is broken and the substituent in the 6 position is $\mathrm{COOH}$ and $\mathrm{CH}_{2} \mathrm{COOH}$ in the $\gamma$ position.

chlorins. No trace of free-base or metalloporphyrin was found in these shallow sediments. Peake et al. (1974) reported that phyllo and etio type free-base porphyrins were mass spectrometrically observable in surface $(0-68 \mathrm{~cm})$ sediments of the Black Sea. However, these investigators did not report UV-visible spectra in support of these data. In contrast, in the study reported here, free-base porphyrins were found only in sediments at and below 500 meters depth of burial. These proved to be of the DPEP series; phyllo and etio series pigments were absent.

In addition, our chlorin mass spectrometric data (Table 2) do not support the speculation that homologous series, 14 mass units apart, exists in the chlorin fractions. A truncated series is initially observable only after diagenesis had progressed to the free-base porphyrin stage and then persists throughout the geoporphyrins, whether they are in the metallated or free-base form.

Site 380 , drilled to a depth of 1073.5 meters, provided an opportunity to observe the transition of chlorins to free-base porphyrins. This transition is a dehydrogenation (aromatization of the 7, 8 bond, Figure 3 ) and is probably equivalent to the minimum diagenetic stage where hydrocarbons could be produced from their precursors. The initial appearance of free-base porphyrin was at 680 meters; as depth increased, the concentration of the porphyrin increased relative to the chlorin. At 912 meters, there was 20 times more free-base porphyrin than chlorin and chlorins were not observed below this depth.

The influence of depth of burial as a diagenetic factor was clearly demonstrated by the distribution of these products at Site 380 . Stratigraphic horizons are traceable from site to site, as shown in Figure 1. Horizon D lies at 860 meters depth of burial at Site 380; at this depth, high concentrations of free-base porphyrins were found. In contrast, horizon D is shallower at Site $381(350 \mathrm{~m})$; only chlorins were found at this depth. In this case, free-base porphyrins appeared only in the Miocene core sample at 500 meters (381-54-5). The data presented here may indicate that depth of burial (and its corollary, temperature) is a more important factor in the maturation process of organic matter than geologic age.

Nickel porphyrins were present in the deeper Pleistocene and older sediments along with free-base porphyrin and/or chlorins. Exceptions to this generality are Cores $380 \mathrm{~A}-17$ and $380 \mathrm{~A}-21$ where the nickel porphyrin was the only observable pigment.

A minor portion of the nickel porphyrins, the DPEP series, had a molecular weight distribution similar to that of the free base (Table 3, Cores 380A-78 and 38154). The major portion of the nickel porphyrins, though, is atypical and could not have arisen from simple insertion of nickel into the free-base porphyrin common to those strata. This conclusion is based on the previous finding of the similarities between the molecular weight distributions of nickel porphyrins and free-base porphyrins occurring together in the same sediment (Baker et al., in press a).

These are atypical nickel porphyrins as shown by the UV-visible spectrum, Figure 2. Both the spectra of the metallated and free-base porphyrins indicate a divergence from the DPEP and etio type of spectra observed in all earlier deep-sea studies. The mass spectra (Table 3) show that these are almost totally dealkylated nickel porphyrins with as few as four or five methylene groups attached to the porphyrin nucleus. Dealkylation has proceeded to a greater degree than previously noted in extracts from either deep-sea sediments or crude oil (Baker et al., 1967).

Because these nickel porphyrins are predominantly associated with the Pliocene and Miocene sediment samples and because of their lone occurrence in Cores $380 \mathrm{~A}-17$ and $380 \mathrm{~A}-21$, we suspect that their present distribution may be a result of upward diffusion from the older strata. This information together with the spectral data is offered as an explanation for the suggestion that these are not typical nickel geoporphyrins.

The Black Sea sediments have been described as being characteristically lacustrine with only a few marine phases present (Leg 42B summary). However, no distinctions can be made based on chlorophyll diagenetic products as to the source of the organic matter deposited in this basin. Marine sediments from Legs 40 and 41 contained products similar to those found in the Black Sea.

The data obtained from the hydroxyaluminum chlorins represents the most detailed analysis of these early products yet to be obtained. Application of this method to chlorins of marine origin may yet show differences in diagenetic products not discernible with less sophisticated methods used in the past. However, 
complete interpretation of early chlorophyll diagenetic products is presently lacking.

\section{ACKNOWLEDGMENTS}

This research was supported by the Oceanography Section of the National Science Foundation, Grant DES-74-12438 A01.

We thank Clementine Everritt for her assistance in sample work-up.

We also thank Dr. Karl S. Schorno, Phillips Petroleum Company, Bartlesville, Oklahoma, for his review of the manuscript.

\section{REFERENCES}

Baker, E.W., 1966. Mass spectrometric characterization of petroporphyrins: J. Am. Chem. Soc., v. 88, p. 2311.

Baker, E.W. and Billig, M.T., 1970. Formation of aluminum chlorins and aluminum porphyrins using lithium aluminum hydride as the metallating agent: SoutheastSouthwest Regional Am. Chem. Soc. Mtg., New Orleans, 2-4 December.
Baker, E.W. and Smith, G.D., 1973. Chlorophyll derivatives in sediments, Site 147. In Heezan, B.C., MacGregor, I., et al., Initial Reports of the Deep Sea Drilling Project, Volume 20: Washington (U.S. Government Printing Office), p. 943.

Baker, E.W., Palmer, S.E., and Huang, W.Y., in press a. Chlorin and porphyrin geochemistry of DSDP Leg 40 sediments. In Bolli, H.M., Ryan, W.B.F., et al., Initial Reports of the Deep Sea Drilling Project, Volume 40: Washington (U.S. Government Printing Office). , in press b. Intermediate and late diagenetic tetrapyrrole pigments, Leg 41: Cape Verde Rise and Basin. In Lancelot, Y., Seibold, E., et al., Initial Reports of the Deep Sea Drilling Project, Volume 41: Washington (U.S. Government Printing Office).

Baker, E.W., Yen, T.F., Dickie, J.P., Rhodes, R.E., and Clark, L.F., 1967. Mass spectrometry of porphyrins. II. characterization of petroporphyrins: J. Am. Chem. Soc., v. 89 , p. 3631 .

Peake, E., Casagrande, D.T., and Hodgson, G.W., 1974. Fatty acids, chlorins, hydrocarbons, sterols, and carotenoids from a Black Sea core. In Degens, E. T. and Ross, D. A. (Eds.), The Black Sea-geology, chemistry and biology: Am. Assoc. Petrol. Geol. Mem. 20, p. 505. 